\title{
Respon Morfo-Fisiologi Genotipe Kedelai terhadap Naungan Jagung dan Ubikayu
}

\author{
Morpho-Physiological Response of Soybean Genotypes Under Maize and Cassava Shading
}

\author{
Herdina Pratiwi* dan Rina Artari
}

\author{
Balai Penelitian Tanaman Aneka Kacang dan Umbi \\ Jl. Raya Kendalpayak KM 8 KP 66, Malang 65101, Indonesia
}

Diterima 19 September 2017/Disetujui 14 Maret 2018

\begin{abstract}
Study on soybeans morpho-physiological responses in artificial or natural shade are beneficial to determine the effects of shade on morpho-physiology and yield of soybean. This research was aimed to study the morpho-physiological responses of soybean varieties under shading of maize and cassava compared to arficial shading. The research was conducted in Kendalpayak Research Station, ILETRI, from February to May 2016 used split plot design with three replications. The main plot was three shade sources: N1:black paranet 50\%, N2: maize shade, and N3: cassava shade, while the sub plot was five soybean varieties: Dena 1, Dena 2, Argopuro, Panderman, and Grobogan. Soybean varieties showed morpho-physiology differences depending on the shade source. Soybean grown under shading of cassava had plant height, leaf area ratio, and leaf area lower than under shading of paranet and maize. Cassava shade also caused soybean had higher growth rate, net assimilation rate, and yield than those under paranet and maize shade. Shade-tolerant varieties (Dena 1 and Dena 2) had high yield on all kind of shade. Less tolerant varieties (Panderman and Grobogan) had higher yield under cassava shade and lower yield under paranet and maize shade. Maize crop had similar shade effects with 50\% paranet shade.
\end{abstract}

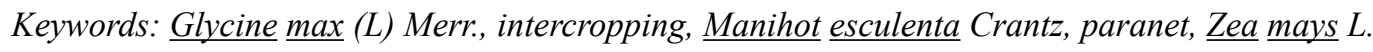

\section{ABSTRAK}

Studi respon morfo-fisiologi kedelai pada berbagai jenis naungan baik buatan maupun alami diperlukan untuk mengetahui efek naungan terhadap morfo-fisiologi dan hasil kedelai. Penelitian bertujuan untuk mempelajari respon morfofisiologi varietas kedelai terhadap naungan jagung dan ubikayu dibandingkan naungan buatan. Penelitian dilaksanakan di Kebun Percobaan Kendalpayak, Balitkabi, pada Februari-Mei 2016 menggunakan rancangan split plot tiga ulangan. Petak utama adalah tiga jenis naungan: N1: naungan paranet hitam 50\%, N2: naungan jagung, dan N3: naungan ubikayu, sedangkan anak petak adalah lima varietas kedelai: Dena 1, Dena 2, Argopuro, Panderman, dan Grobogan. Respon morfofisiologi varietas kedelai menunjukkan perbedaan tergantung sumber naungan. Tanaman kedelai pada naungan ubikayu memiliki tinggi, rasio luas daun, dan masa luas daun lebih rendah dibandingkan dengan naungan paranet dan jagung. Naungan ubikayu juga menyebabkan laju pertumbuhan, laju asimilasi bersih, dan hasil biji kedelai lebih tinggi dari naungan paranet dan jagung. Varietas toleran naungan (Dena 1 dan Dena 2) memberikan hasil yang tinggi ketika ditanam pada ketiga jenis naungan. Varietas kurang toleran (Panderman dan Grobogan) memberikan hasil yang tinggi pada naungan ubikayu dan lebih rendah pada naungan paranet dan jagung. Tanaman jagung berpotensi memberikan efek naungan yang tidak berbeda dengan naungan paranet $50 \%$.

Kata kunci: Glycine $\underline{\max }$ (L) Merr., Manihot esculenta Crantz, paranet, tumpangsari, Zea mays $L$.

\section{PENDAHULUAN}

Radiasi matahari sangat mempengaruhi pertumbuhan dan produktivitas tanaman melalui proses fotosintesis. Tanaman beradaptasi terhadap perubahan iradiasi dengan modifikasi morfologi dan fisiologi, sehingga energi cahaya yang tersedia dapat digunakan secara efisien (Koike,

* Penulis untuk korespondensi. e-mail: herdina_p@mail.com
2013). Kekurangan cahaya akibat naungan menyebabkan perubahan morfo-fisiologi tanaman, seperti meningkatnya luas daun spesifik, panjang dan lebar daun, namun di sisi lain menurunkan diamater batang dan total bahan kering tanaman (Perrin et al., 2013). Sundari dan Susanto (2015) melaporkan bahwa intensitas naungan hingga 75\% meningkatkan tinggi tanaman dan luas daun spesifik, tetapi mengurangi jumlah dan luas daun, laju penyerapan cahaya, laju fotosintesis, indeks klorofil daun, jumlah polong isi, dan bobot biji per tanaman kedelai. 
Setiap genotipe tanaman memiliki toleransi yang berbeda terhadap cekaman naungan. Tanaman yang adaptif terhadap radiasi rendah mengalami peningkatan rasio luas daun, rasio daun batang, panjang batang, dan penurunan ketebalan daun (Haque et al., 2009). Sundari et al. (2016) melaporkan bahwa pertumbuhan dan hasil tanaman kedelai dipengaruhi oleh interaksi genotipe kedelai dengan lingkungan. Penelitian tentang respon genotipe tanaman terhadap naungan lebih banyak dilakukan menggunakan lingkungan naungan termodifikasi seperti paranet atau kain hitam. Naungan buatan juga banyak digunakan untuk analisis pertumbuhan dan morfo-fisiologi tanaman kedelai (Muhuria et. al., 2006; Kisman et. al., 2007; Chairudin et al., 2015). Studi respon morfo-fisiologi kedelai pada berbagai jenis naungan baik buatan maupun alami diperlukan untuk mengetahui efek naungan terhadap morfo-fisiologi dan hasil kedelai. Penelitian bertujuan untuk mempelajari respon morfo-fisiologi varietas kedelai terhadap naungan jagung dan ubikayu dibandingkan naungan buatan.

\section{BAHAN DAN METODE}

Penelitian dilaksanakan di Kebun Percobaan (KP) Kendalpayak, Malang pada bulan Februari-Mei 2016. Penempatan perlakuan didasarkan pada rancangan split plot tiga ulangan. Petak utama adalah naungan terdiri dari tiga jenis naungan, yaitu: naungan buatan (paranet hitam) 50\% (N1), naungan jagung (N2), dan naungan ubikayu (N3); sedangkan anak petak adalah lima varietas kedelai yaitu: Dena 1 (V1), Dena 2 (V2), Argopuro (V3), Panderman (V4), dan Grobogan (V5). Jagung yang digunakan adalah varietas Pertiwi 3 dan ubikayu yang digunakan adalah varietas Malang 4. Jenis tanah yang dipergunakan adalah Entisol berat. Curah hujan selama penelitian sebesar 428 mm dengan rata-rata $107 \mathrm{~mm}$ per bulan dan intensitas hujan tertinggi pada bulan Februari yaitu $208 \mathrm{~mm}$. Suhu udara berkisar antara $25-29{ }^{\circ} \mathrm{C}$.

Jagung dan ubikayu ditanam baris ganda dengan jarak tanam jagung $220 \mathrm{~cm}$ x $50 \mathrm{~cm}$ x $20 \mathrm{~cm}$ dan ubikayu 220 $\mathrm{cm}$ x $60 \mathrm{~cm}$ x $50 \mathrm{~cm}$. Ukuran plot jagung $7.35 \mathrm{~m}^{2}$ sedangkan plot ubikayu $7.5 \mathrm{~m}^{2}$. Di antara baris ganda jagung dan ubikayu, kedelai ditanam dengan jarak tanam $35 \mathrm{~cm}$ x 15 $\mathrm{cm}$, dua tanaman per rumpun. Ukuran plot kedelai pada semua perlakuan naungan adalah $6.2 \mathrm{~m}^{2}$. Kedelai ditanam setelah tanaman jagung dan ubikayu berumur 24 hari.

Pemupukan kedelai dilakukan pada saat tanam dengan menggunakan dosis $75 \mathrm{~kg}$ Urea $+100 \mathrm{~kg} \mathrm{SP} 36+100 \mathrm{~kg}$ $\mathrm{KCl} \mathrm{ha}{ }^{-1}$. Pemupukan jagung dilakukan pada saat tanam dengan dosis $250 \mathrm{~kg}$ Urea $+100 \mathrm{~kg} \mathrm{SP} 36+100 \mathrm{~kg} \mathrm{KCl}$ $\mathrm{ha}^{-1}$. Pemupukan ubikayu dilakukan secara bertahap, tahap pertama pada saat tanam dengan dosis pupuk Urea $100 \mathrm{~kg}$, SP36 $100 \mathrm{~kg}$ dan $\mathrm{KCl} 50 \mathrm{~kg} \mathrm{ha}^{-1}$, dan tahap kedua pada saat ubikayu berumur 3 bulan dengan menggunakan Urea 100 $\mathrm{kg}$ dan $\mathrm{KCl} 50 \mathrm{~kg} \mathrm{ha}{ }^{-1}$.

Pengamatan dilakukan terhadap parameter morfofisiologi tanaman berdasarkan Gardner et al. (1991) meliputi tinggi tanaman, rasio luas daun (RLD), masa luas daun (MLD), laju pertumbuhan tanaman (LPT), dan laju asimilasi bersih (LAB). Pengamatan morfo-fisiologi tanaman dilakukan setiap dua minggu sekali secara destruktif dengan mengambil satu rumpun tanaman (dua tanaman per rumpun) mulai umur 19 hari setelah tanam (HST) sampai umur 61 HST. Sampel tanaman dipisahkan antara daun, batang dan akar kemudian dioven pada suhu $70{ }^{\circ} \mathrm{C}$ selama 48 jam. Bobot kering sampel digunakan untuk pengamatan morfo-fisiologi yaitu:

Rasio luas daun $(\mathrm{RLD})=\frac{(\mathrm{LDi} / \mathrm{BKTi})+(\mathrm{LDi}-1 / \mathrm{BKTi}-1)}{2}\left(\mathrm{~cm}^{2} \mathrm{~g}^{-1}\right)$ Masa luas daun (MLD) (hari) $=\left(\left(I L \stackrel{2}{D}_{i}+I L D_{i-1}\right) x\left(T_{i}+T_{i-1}\right)\right) / 2$ Laju pertumbuhan tanaman $(\mathrm{LPT})=$ $\frac{((\mathrm{BKTi}-\mathrm{BKTi}-1) /(\mathrm{T}-\mathrm{Ti}-1))}{\mathrm{Ga}}\left(\mathrm{g} \mathrm{cm}^{-2}\right.$ per hari $)$

Laju asimilasi bersih $(\mathrm{LAB})=$ $\frac{(B K T i-B K T i-1)}{(T i-T i-1}+\frac{(\ln L D i-\ln L D i-1)}{(L D i-L D i-1)}\left(\mathrm{g} \mathrm{cm}^{-2}\right.$ per minggu $)$

LDi dan LD i-1 merupakan luas daun $\left(\mathrm{cm}^{2}\right.$ per tanaman) pada Ti dan Ti-1. ILDi dan ILD i-1 merupakan indeks luas daun $\left(\mathrm{cm}^{2}\right.$ per tanaman) pada Ti dan Ti-1. Ga merupakan luas tanah yang ditempati tanaman $\left(\mathrm{cm}^{2}\right)$. Ti dan Ti-1 adalah umur tanaman pada hari ke i dan i-1. BKDi dan BKDi-1 adalah bobot kering daun (g per tanaman) pada $\mathrm{Ti}$ dan Ti-1. BKTi dan BKTi-1 merupakan bobot kering total (g per tanaman) pada Ti dan Ti-1.

Pengamatan terhadap intensitas cahaya matahari dilakukan sebanyak 44 kali dimulai saat tanaman berumur 7 HST hingga umur panen, antara jam 12.00-13.00 WIB dengan menggunakan Lux meter. Pengamatan intensitas cahaya dilakukan pada kanopi kedelai yaitu di bawah daun ketiga dari atas. Pengamatan hasil panen meliputi hasil biji kedelai, bobot tongkol jagung, dan bobot umbi ubikayu. Data dianalisis berdasarkan rancangan split plot faktorial, tiga ulangan. Perbedaan dua nilai tengah diuji dengan menggunakan BNT (Beda Nyata Terkecil) taraf $\alpha \quad 5 \%$. Analisis korelasi dilakukan untuk mengetahui hubungan antar parameter morfo-fisiologi dengan hasil kedelai.

\section{HASIL DAN PEMBAHASAN}

\section{Pola Intensitas Cahaya Matahari pada Berbagai Jenis Naungan}

Penerimaan cahaya pada masing-masing lingkungan naungan mengalami fluktuasi (Gambar 1). Rata-rata intensitas cahaya pada lingkungan paranet sebesar 324 lux, naungan jagung 332 lux, dan naungan ubikayu sebesar 340 lux. Rata-rata intensitas cahaya yang diterima kedelai di bawah naungan jagung dan ubikayu masing-masing $2.56 \%$ dan $5.18 \%$ lebih tinggi dibandingkan naungan paranet. Sesuai dengan spesifikasinya, naungan paranet menurunkan intensitas cahaya matahari yang diterima kedelai sebesar 50\%. Hamdani et al. (2016) melaporkan bahwa pada percobaan naungan tanaman kentang di dataran medium, paranet dan naungan jagung menurunkan intensitas cahaya yang relatif sama yaitu sekitar 32-33\%. Pada penelitian ini, selisih antara intensitas cahaya yang diterima kedelai pada 


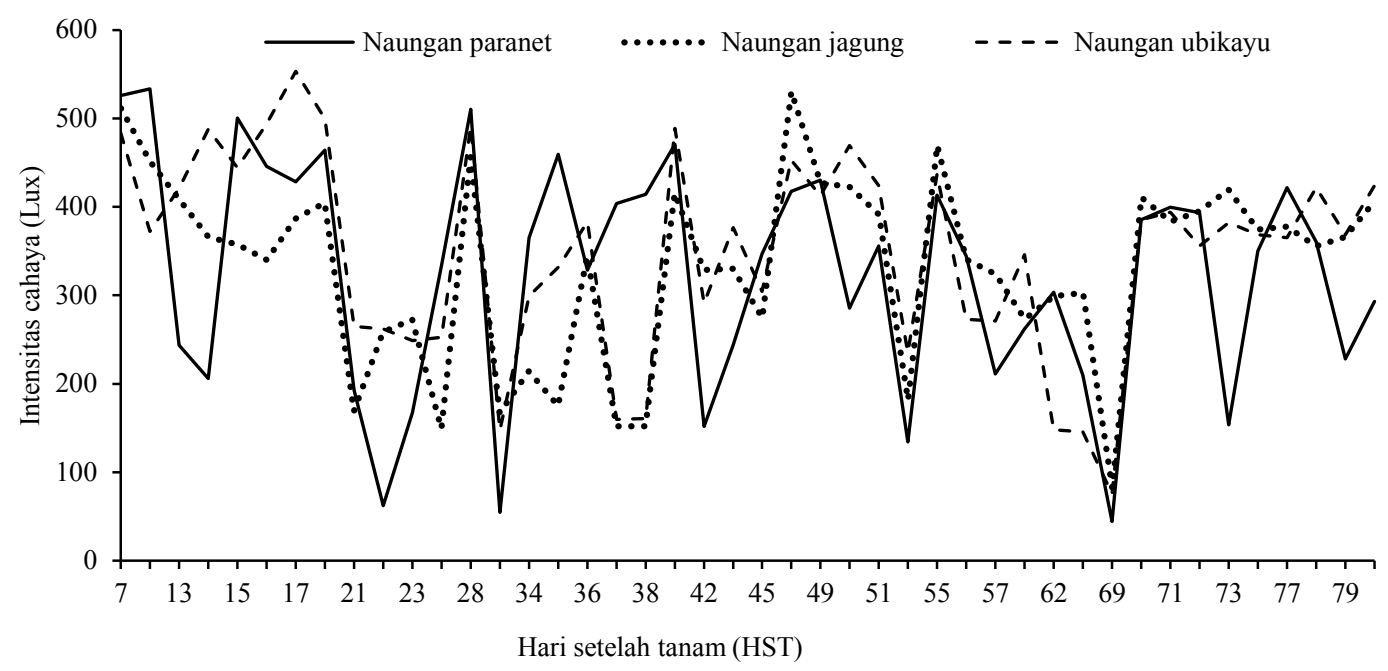

Gambar 1. Intensitas cahaya yang diterima tanaman kedelai pada tiga jenis naungan

naungan paranet dan jagung lebih kecil daripada naungan ubikayu, artinya tanaman jagung memberikan efek naungan yang hampir sama dengan paranet.

\section{Tinggi Tanaman}

Pengaruh interaksi antara jenis naungan dan varietas terhadap tinggi tanaman kedelai disajikan pada Tabel 1 . Pada ketiga jenis naungan, tinggi tanaman varietas Dena 1 dan Panderman lebih tinggi dibandingkan Argopuro, Dena 2 dan Grobogan. Rata-rata tinggi tanaman di naungan jagung tidak berbeda nyata dengan naungan paranet, sedangkan di naungan ubikayu $15 \%$ lebih rendah dari naungan paranet. Hal ini sesuai dengan penelitian Jenabiyan et al. (2014) bahwa kedelai memiliki keragaan tanaman yang lebih rendah pada intensitas cahaya tinggi.

\section{Rasio Luas Daun}

Naungan paranet cenderung meningkatkan rasio luas daun kedelai terutama pada umur 33 dan 47 HST ( $\operatorname{Pr}>$ F 0.09 dan 0.08), sedangkan rasio luas daun tidak berbeda antar varietas kedelai (Tabel 2). Naungan paranet memberikan rasio luas daun terbesar diikuti naungan jagung dan ubikayu.
Naungan jagung memberikan rasio luas daun kedelai 9.91\% dan $9.40 \%$ lebih rendah dari naungan paranet pada umur 33 dan 47 HST, sedangkan pada umur 61 HST lebih tinggi dari naungan paranet. Naungan ubikayu menyebabkan RLD kedelai berturut-turut 23.78\%, 21.54\%, 7.69\% lebih rendah dibandingkan naungan paranet pada umur 33, 47 dan 61 HST. Rasio luas daun yang lebih tinggi meningkatkan efisiensi dalam penangkapan cahaya pada intensitas cahaya yang rendah, karena tanaman mengalokasikan lebih banyak biomassa ke daun dan membentuk daun yang lebih tipis (Cheng et al., 2013).

\section{Masa Luas Daun}

Jenis naungan berpengaruh nyata terhadap masa luas daun pada umur 33 dan 47 HST (Tabel 3). Pada umur 33 HST, masa luas daun kedelai pada naungan jagung dan ubikayu berturut-turut mencapai $31.23 \%$ dan $40.20 \%$ lebih rendah dari naungan paranet. Pada umur 47 HST masa luas daun kedelai pada naungan jagung dan ubikayu berturut-turut mencapai $25.87 \%$ dan $35.66 \%$ lebih rendah dari naungan paranet. Juraimi et al. (2014) melaporkan bahwa naungan paranet dan naungan alami menghasilkan masa luas daun yang tidak berbeda apabila penghambatan intensitas cahaya

Tabel 1. Tinggi tanaman varietas kedelai saat panen pada berbagai jenis naungan

\begin{tabular}{lccc}
\hline \multirow{2}{*}{ Varietas } & \multicolumn{3}{c}{ Tinggi tanaman $(\mathrm{cm})$} \\
\cline { 2 - 4 } & Naungan paranet & Naungan jagung & Naungan ubikayu \\
\hline Dena 1 & $91.37 \mathrm{a}$ & $91.13 \mathrm{a}$ & $77.70 \mathrm{c}$ \\
Dena 2 & $67.17 \mathrm{e}$ & $70.50 \mathrm{~d}$ & $55.43 \mathrm{~g}$ \\
Argopuro & $71.67 \mathrm{~d}$ & $75.83 \mathrm{c}$ & $71.67 \mathrm{~d}$ \\
Panderman & $84.90 \mathrm{~b}$ & $88.73 \mathrm{a}$ & $74.80 \mathrm{c}$ \\
Grobogan & $66.27 \mathrm{e}$ & $70.80 \mathrm{~d}$ & $62.43 \mathrm{f}$ \\
\hline Koefisien keragaman $(\%)$ & & 2.49 & \\
\hline
\end{tabular}

Keterangan: Angka yang diikuti huruf yang sama pada kolom dan baris yang sama tidak berbeda pada uji BNT taraf $\alpha$ 5\% 
Tabel 2. Rasio luas daun (leaf area ratio) kedelai akibat pengaruh jenis naungan dan varietas

\begin{tabular}{|c|c|c|c|}
\hline \multirow{2}{*}{ Perlakuan } & \multicolumn{3}{|c|}{ Rasio luas daun $\left(\mathrm{cm}^{2} \mathrm{~g}^{-1}\right)$} \\
\hline & $33 \mathrm{HST}$ & $47 \mathrm{HST}$ & $61 \mathrm{HST}$ \\
\hline \multicolumn{4}{|l|}{ Jenis naungan } \\
\hline Naungan paranet & 70.96 & 80.87 & 38.07 \\
\hline Naungan jagung & 63.94 & 73.26 & 44.36 \\
\hline Naungan ubikayu & 54.09 & 63.45 & 35.14 \\
\hline \multicolumn{4}{|l|}{ Varietas kedelai } \\
\hline Dena 1 & 64.69 & 80.66 & 42.27 \\
\hline Dena 2 & 56.86 & 64.17 & 34.89 \\
\hline Argopuro & 68.97 & 77.22 & 50.14 \\
\hline Panderman & 57.45 & 65.74 & 33.64 \\
\hline Grobogan & 67.02 & 74.84 & 35.01 \\
\hline Koefisien keragaman (\%) & 17.43 & 15.32 & 18.63 \\
\hline
\end{tabular}

Keterangan: Data yang dianalisis merupakan hasil transformasi $\sqrt{ }(\mathrm{x}+0.5)$. HST $=$ Hari setelah tanam. Angka pada kolom dan perlakuan yang sama tidak berbeda pada uji BNT taraf $\alpha 5 \%$

Tabel 3. Masa luas daun (leaf area duration) kedelai akibat pengaruh jenis naungan dan varietas

\begin{tabular}{|c|c|c|c|c|}
\hline \multirow{2}{*}{ Perlakuan } & \multicolumn{4}{|c|}{ Masa luas daun (hari) } \\
\hline & $19 \mathrm{HST}$ & $33 \mathrm{HST}$ & $47 \mathrm{HST}$ & $61 \mathrm{HST}$ \\
\hline \multicolumn{5}{|l|}{ Jenis naungan } \\
\hline Naungan paranet & $3.01 \mathrm{a}$ & $7.15 \mathrm{a}$ & $19.22 \mathrm{a}$ & $29.04 \mathrm{a}$ \\
\hline Naungan jagung & $2.07 \mathrm{~b}$ & $5.30 \mathrm{~b}$ & $20.80 \mathrm{a}$ & $33.97 \mathrm{a}$ \\
\hline Naungan ubikayu & $1.80 \mathrm{~b}$ & $4.60 \mathrm{~b}$ & $17.50 \mathrm{a}$ & $28.38 \mathrm{a}$ \\
\hline \multicolumn{5}{|l|}{ Varietas kedelai } \\
\hline Dena 1 & $2.45 \mathrm{a}$ & $6.70 \mathrm{a}$ & $22.04 \mathrm{a}$ & $33.75 \mathrm{a}$ \\
\hline Dena 2 & $1.94 \mathrm{a}$ & $4.72 \mathrm{a}$ & $18.02 \mathrm{a}$ & $29.64 a$ \\
\hline Argopuro & $2.12 \mathrm{a}$ & $4.98 \mathrm{a}$ & $20.20 \mathrm{a}$ & $33.94 \mathrm{a}$ \\
\hline Panderman & $2.03 \mathrm{a}$ & $5.03 \mathrm{a}$ & $16.57 \mathrm{a}$ & $26.13 \mathrm{a}$ \\
\hline Grobogan & $2.92 \mathrm{a}$ & $6.98 \mathrm{a}$ & $19.04 \mathrm{a}$ & $28.85 \mathrm{a}$ \\
\hline Koefisien keragaman (\%) & 18.43 & 18.27 & 15.97 & 18.70 \\
\hline
\end{tabular}

Keterangan: Data yang dianalisis merupakan hasil transformasi $\sqrt{ }(x+0.5)$. HST $=$ Hari setelah tanam. Angka yang diikuti huruf yang sama pada kolom dan perlakuan yang sama tidak berbeda pada uji BNT taraf $\alpha$ 5\%

oleh naungan alami tersebut sama dengan naungan paranet. Pada penelitian ini penghambatan intensitas cahaya matahari yang lebih besar pada naungan paranet meningkatkan masa luas daun kedelai.

Masa luas daun tidak berbeda antar varietas kedelai pada semua umur pengamatan. Hal tersebut menunjukkan bahwa kelima varietas kedelai memiliki kapasitas penyerapan cahaya untuk asimilasi yang sama sepanjang waktu.

\section{Laju Pertumbuhan Tanaman}

Laju pertumbuhan tanaman (LPT) menunjukkan kecepatan penumpukan bahan kering tanaman per hari per luasan tanah tertentu. Laju pertumbuhan tanaman sangat rendah pada awal pertumbuhan (0-19 HST) yaitu kurang dari $1 \times 10^{-4} \mathrm{~g} \mathrm{~cm}^{-2}$ per hari kemudian mulai meningkat pada umur 20-33 HST dan mencapai puncaknya pada umur 48$61 \mathrm{HST}$ yang mencapai $50 \times 10^{-4} \mathrm{~g} \mathrm{~cm}^{-2}$ per hari (Gambar $2,3,4,5)$. Laju pertumbuhan tanaman kedelai dipengaruhi oleh interaksi antara jenis naungan dan varietas kedelai pada umur 0-19 HST dan 34-47 HST.

Pada umur 0-19 HST varietas Dena 1 memiliki laju pertumbuhan yang paling tinggi pada naungan paranet, namun menurun ketika berada di naungan jagung dan ubikayu. Varietas Dena 2 dan Argopuro memiliki laju pertumbuhan terendah dibandingkan varietas lainnya pada semua jenis naungan (Gambar 2). 


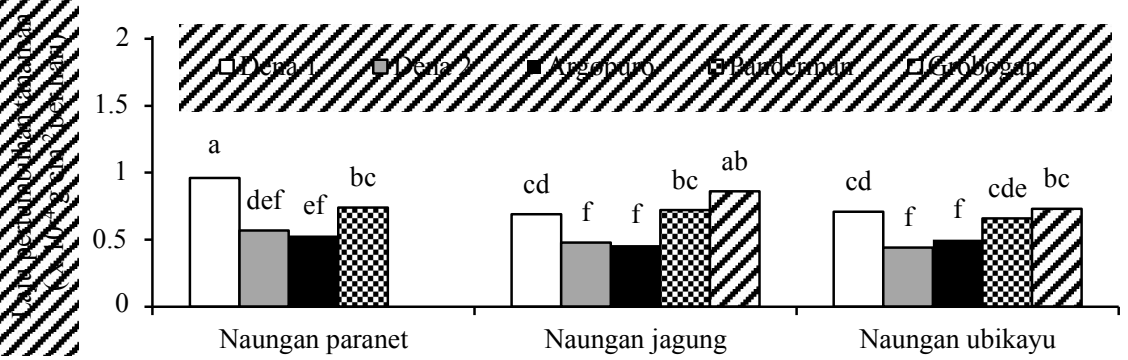

Gambar 2. Laju pertumbuhan varietas kedelai pada tiga jenis naungan pada umur 0-19 HST. Nilai yang diikuti huruf yang sama, tidak berbeda pada uji BNT taraf $\alpha 5 \%$

Pada umur 20-33 HST, jenis naungan dan varietas secara terpisah berpengaruh terhadap LPT (Gambar 3). Naungan paranet menyebabkan LPT kedelai lebih tinggi dibandingkan naungan jagung dan ubikayu yaitu mencapai $3.5 \times 10^{-4} \mathrm{~g} \mathrm{~cm}^{-2}$ per hari, sedangkan naungan jagung dan ubikayu tidak berbeda (Gambar 3A). Varietas Grobogan dan Dena 1 memiliki LPT lebih tinggi dibandingkan varietas Dena 2, Argopuro dan Panderman (Gambar 3B).

Pada umur 34-47 HST, LPT antar varietas kedelai berbeda nyata pada naungan paranet dan jagung, namun menjadi tidak berbeda ketika berada di naungan ubikayu (Gambar 4). Pada naungan paranet, LPT tertinggi dimiliki varietas Grobogan dan terendah adalah Argopuro. Pada naungan jagung, LPT tertinggi dimiliki varietas Panderman dan terendah Argopuro.

Pada umur 48-61 HST, LPT kedelai hanya dipengaruhi oleh varietas (Gambar 5). Varietas Dena 1 memiliki LPT yang tinggi yaitu $50 \times 10^{-4} \mathrm{~g} \mathrm{~cm}^{-2}$ per hari, sedangkan varietas Argopuro memiliki LPT yang terendah.

Pola respon LPT varietas kedelai pada naungan jagung hampir sama dengan naungan paranet, sedangkan LPT pada naungan ubikayu cenderung tidak berbeda antar varietas. Laju pertumbuhan tanaman dipengaruhi oleh kemampuan tanaman menangkap photosynthetic active radiation (PAR) untuk akumulasi bahan kering sehingga semakin besar cahaya yang diterima maka semakin besar LPT (Addo-
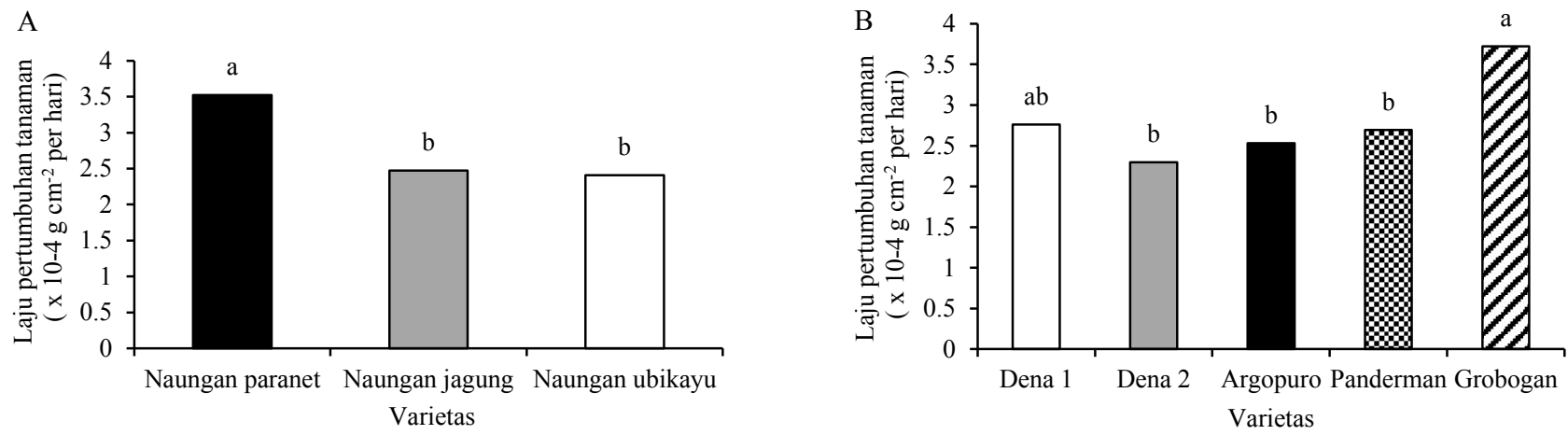

Gambar 3. Laju pertumbuhan kedelai pada umur 20-33 HST akibat pengaruh jenis naungan (A) dan varietas (B). Nilai yang diikuti huruf yang sama tidak berbeda pada uji BNT taraf $\alpha 5 \%$

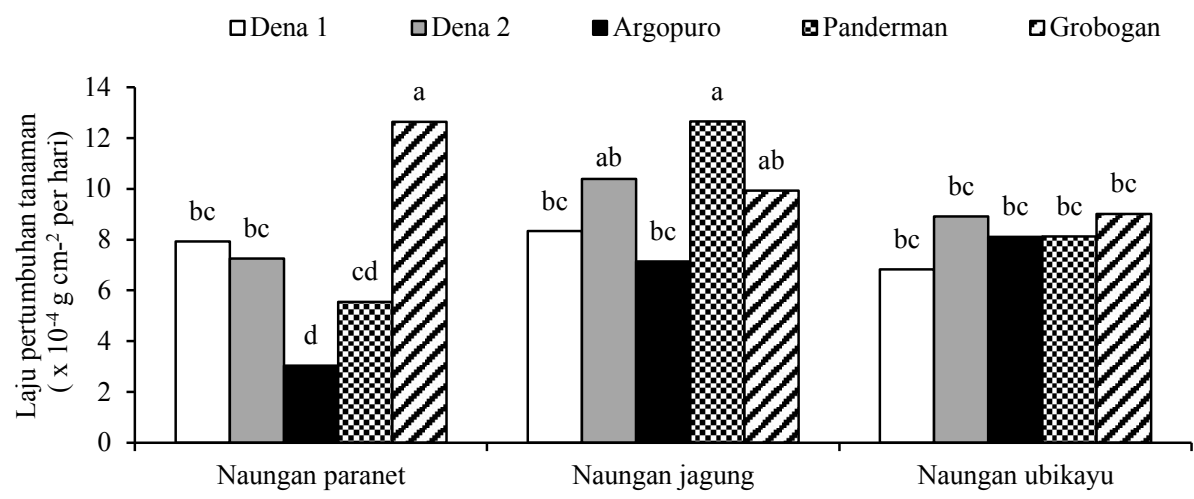

Gambar 4. Laju pertumbuhan varietas kedelai pada tiga jenis naungan pada umur 34-47 HST. Nilai yang diikuti huruf yang sama tidak berbeda pada uji BNT taraf $\alpha 5 \%$ 


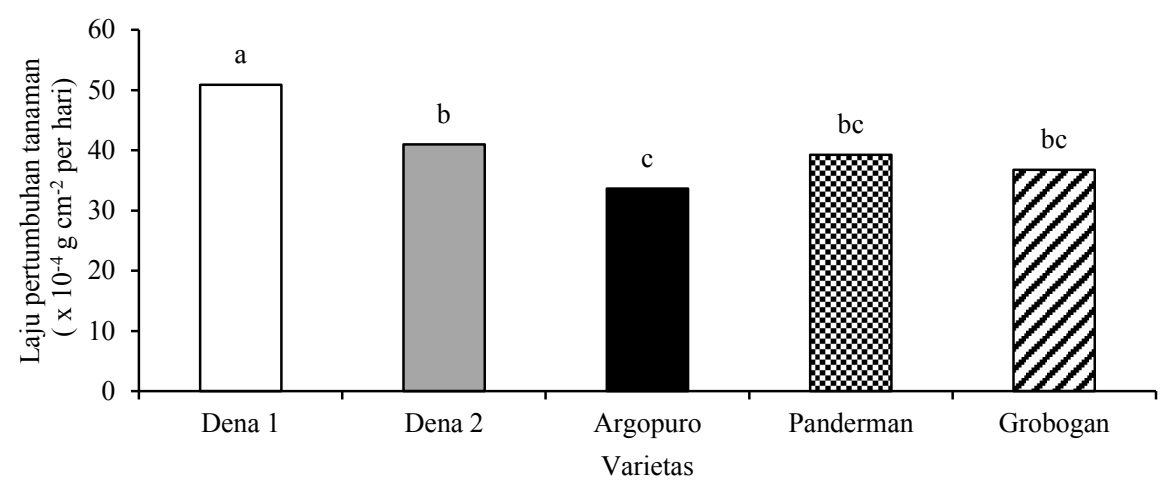

Gambar 5. Laju pertumbuhan varietas kedelai pada umur 48-61 HST. Nilai yang diikuti huruf yang sama tidak berbeda pada uji BNT taraf a $5 \%$

Quaye et al., 2011). Intensitas cahaya matahari yang diterima kedelai dipengaruhi oleh jenis naungan. Efek naungan dari paranet lebih stabil dan seragam sedangkan efek naungan pada tumpangsari kedelai+jagung atau kedelai+ubikayu dipengaruhi oleh kecepatan penutupan kanopi jagung dan ubikayu. Perkembangan ubikayu relatif lambat pada tiga bulan pertama pertumbuhan, sedangkan jagung relatif lebih cepat. Hal tersebut menyebabkan tanaman kedelai mendapatkan efek penaungan yang lebih besar oleh kanopi jagung dibanding kanopi ubikayu. Hal tersebut sesuai dengan penelitian Addo-Quaye et al. ( 2011) bahwa tanaman kedelai yang ditanam 28 hari setelah tanaman jagung memiliki indeks luas daun dan laju pertumbuhan tanaman yang lebih rendah dibandingkan kedelai yang ditanam 14 hari sebelum atau bersamaan dengan tanaman jagung karena mendapat naungan yang lebih tinggi dari kanopi jagung.

\section{Laju Asimilasi Bersih}

Gambar 6 dan 7 menunjukkan pengaruh interaksi antara jenis naungan dengan varietas terhadap laju asimilasi bersih kedelai. Pada naungan paranet, varietas Grobogan cenderung memiliki laju asimilasi bersih lebih tinggi dibandingkan varietas lainnya pada umur 33 dan 47 HST, namun LAB Grobogan menjadi rendah ketika berada di naungan jagung dan ubikayu.

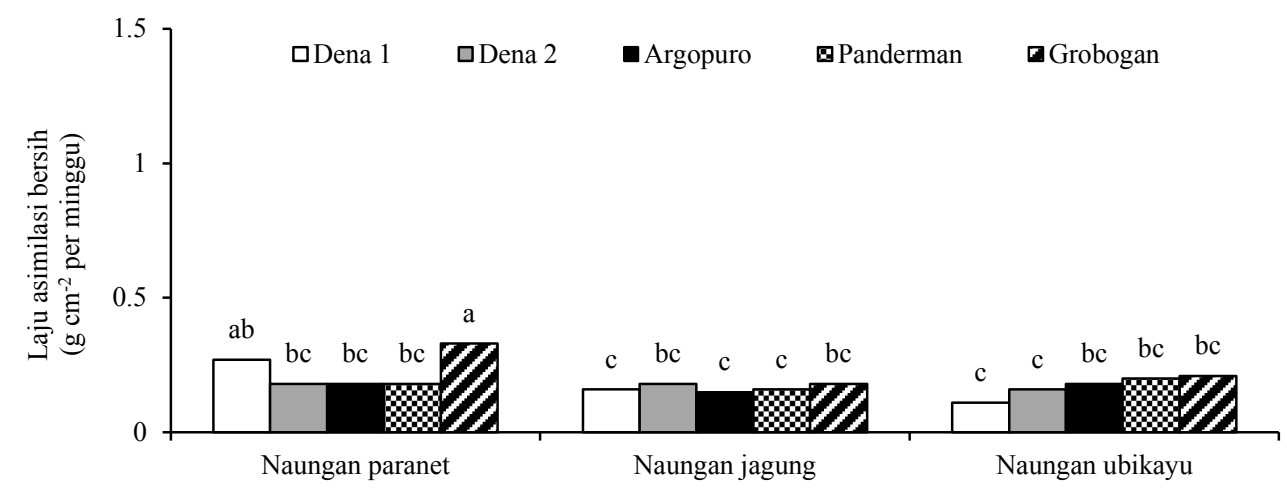

Gambar 6. Laju asimilasi bersih varietas kedelai pada tiga jenis naungan pada umur 33 HST. Nilai yang diikuti huruf yang sama, tidak berbeda pada uji BNT taraf $\alpha 5 \%$

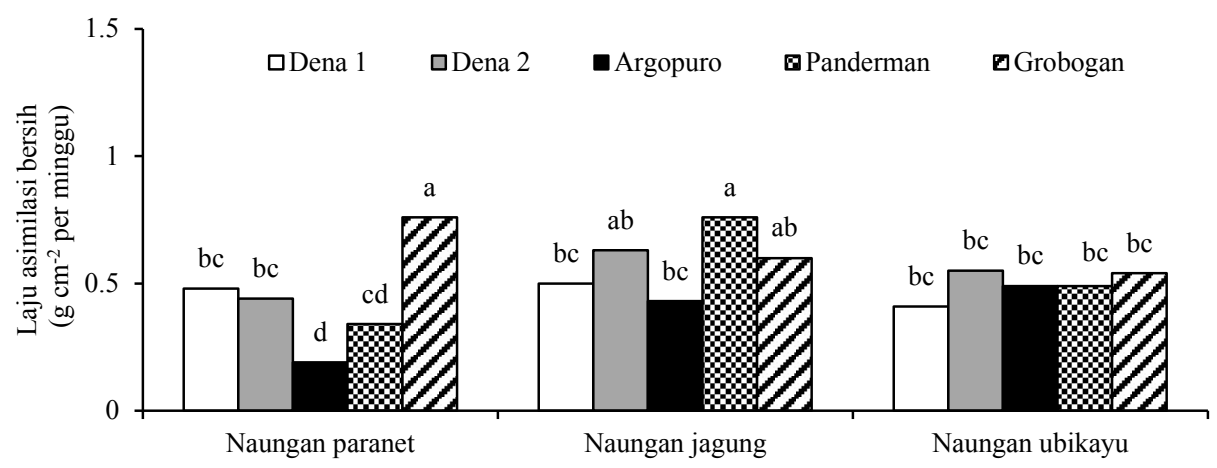

Gambar 7. Laju asimilasi bersih varietas kedelai pada tiga jenis naungan pada umur 47 HST. Nilai yang diikuti huruf yang sama, tidak berbeda pada uji BNT taraf $\alpha 5 \%$ 
Pada umur 61 HST, laju asimilasi bersih kedelai meningkat dibandingkan umur sebelumnya dan hanya dipengaruhi oleh varietas (Gambar 8). Artinya kelima varietas kedelai memberikan respon laju asimilasi bersih yang sama pada jenis naungan yang berbeda. Bertambahnya luas daun seiring dengan bertambahnya umur tanaman menyebabkan peningkatan laju asimilasi bersih. Pada umur 61 HST, varietas Dena 1 memiliki LAB yang lebih tinggi dibandingkan keempat varietas lainnya yaitu dengan laju asimilasi bersih sebesar $3.05 \mathrm{~g} \mathrm{~cm}^{-2}$ per minggu sedangkan Argopuro memiliki laju asimilasi bersih paling rendah yaitu sebesar $2.02 \mathrm{~g} \mathrm{~cm}^{-2}$ per minggu.

Varietas Dena 1 menunjukkan respon toleran terhadap cekaman naungan dilihat dari nilai laju asimilasi bersih yang cenderung tetap tinggi meskipun ternaungi hingga 50\%. Argopuro merupakan varietas yang paling sensitif terhadap naungan terlihat dari rendahnya LAB terutama pada naungan paranet. Peng et al. (2015) melaporkan bahwa asimilasi bersih semakin menurun dengan semakin rendahnya radiasi matahari PAR yang diterima oleh tanaman. Variasi yang terjadi pada radiasi matahari yang diterima tanaman kedelai pada sistem tumpangsari dipengaruhi oleh jenis tanaman utama dan jarak barisan kedelai terhadap barisan tanaman utama, semakin dekat tanaman kedelai ke sumber naungan semakin rendah radiasi matahari vang diterima.

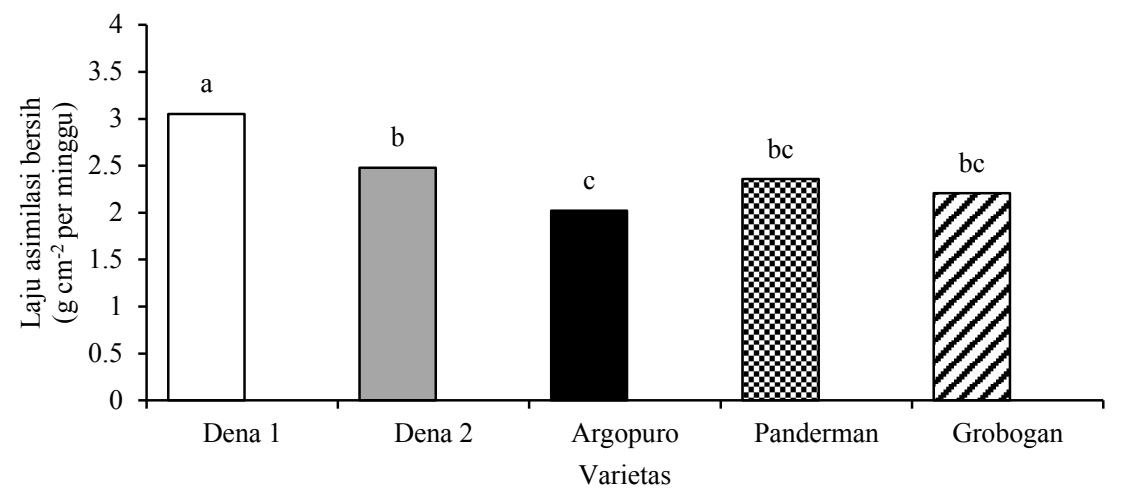

Gambar 8. Laju asimilasi bersih varietas kedelai pada umur 61 HST. Nilai yang diikuti huruf yang sama, tidak berbeda pada uji BNT taraf $\alpha 5 \%$

Tabel 4. Hasil biji kedelai, tongkol jagung, dan ubikayu

\begin{tabular}{lccccc}
\hline \multirow{2}{*}{ Perlakuan } & Naungan paranet & \multicolumn{2}{c}{ Naungan jagung } & \multicolumn{2}{c}{ Naungan ubikayu } \\
\cline { 2 - 6 } & $\begin{array}{c}\text { Hasil kedelai } \\
\text { (kg biji per plot) }\end{array}$ & $\begin{array}{c}\text { Hasil kedelai } \\
\text { (kg biji per plot) }\end{array}$ & $\begin{array}{c}\text { Hasil jagung } \\
\text { (kg tongkol per plot) }\end{array}$ & $\begin{array}{c}\text { Hasil kedelai } \\
\text { (kg biji per plot) }\end{array}$ & $\begin{array}{c}\text { Hasil ubikayu } \\
\text { (kg umbi segar per plot) }\end{array}$ \\
\hline Dena 1 & $0.68 \mathrm{~d}$ & $0.44 \mathrm{ef}$ & $5.37 \mathrm{a}$ & $1.26 \mathrm{a}$ & $9.33 \mathrm{~b}$ \\
Dena 2 & $0.69 \mathrm{~d}$ & $0.65 \mathrm{~d}$ & $4.83 \mathrm{a}$ & $0.98 \mathrm{c}$ & $11.53 \mathrm{a}$ \\
Argopuro & $0.69 \mathrm{~d}$ & $0.43 \mathrm{fg}$ & $5.53 \mathrm{a}$ & $1.16 \mathrm{~b}$ & $12.33 \mathrm{a}$ \\
Panderman & $0.49 \mathrm{e}$ & $0.40 \mathrm{fg}$ & $5.53 \mathrm{a}$ & $0.69 \mathrm{~d}$ & $7.77 \mathrm{c}$ \\
Grobogan & $0.39 \mathrm{~g}$ & $0.45 \mathrm{ef}$ & $4.43 \mathrm{a}$ & $0.99 \mathrm{c}$ & $12.43 \mathrm{a}$ \\
\hline Rata-rata & 0.59 & 0.47 & 5.14 & 1.02 & 10.68 \\
\hline
\end{tabular}

Keterangan: Angka yang diikuti huruf yang sama pada kolom dan baris pada perlakuan dan variabel yang sama tidak berbeda pada uji BNT taraf $\alpha 5 \%$. Luas plot kedelai $6.2 \mathrm{~m}^{2}$, jagung $7.35 \mathrm{~m}^{2}$, ubikayu $7.5 \mathrm{~m}^{2}$ 
varietas kedelai. Ubikayu yang ditanam tumpangsari dengan varietas Dena2, Argopuro dan Grobogan menghasilkan umbi yang lebih tinggi dibandingkan dengan varietas Dena 1 dan Panderman. Umbi ubikayu terendah dihasilkan oleh tumpangsari ubikayu dengan Panderman. Hal tersebut diduga karena Panderman memiliki umur yang lebih panjang dibandingkan keempat varietas lainnya sehingga ubikayu mengalami kompetisi yang lebih lama dalam mendapatkan hara.

Hasil analisis korelasi menunjukkan bahwa morfofisiologi tanaman kedelai berkorelasi nyata dengan hasil kedelai pada naungan paranet sedangkan pada naungan jagung dan ubikayu tidak berkorelasi nyata. Pada naungan paranet, hasil kedelai berkorelasi positif dengan rasio luas daun pada umur $61 \mathrm{HST}\left(\mathrm{r}=0.70^{* *}\right)$ dan laju pertumbuhan tanaman pada umur 0-19 HST $\left(\mathrm{r}=0.57^{*}\right)$. Artinya bahwa peningkatan rasio luas daun dan LPT di awal pertumbuhan tanaman berhubungan erat dengan hasil biji kedelai yang menunjukkan bahwa semakin tingginya efisiensi daun dalam menangkap cahaya matahari untuk dialokasikan ke biji, penumpukan bahan kering sudah dimulai dengan baik pada awal pertumbuhan (umur 0-19 HST). Tidak berkorelasinya morfo-fisiologi dengan hasil kedelai pada naungan jagung dan ubikayu disebabkan oleh tidak seragamnya efek naungan oleh tanaman jagung dan ubikayu sehingga respon tanaman kedelai menjadi beragam.

\section{KESIMPULAN}

Efek naungan dari tanaman ubikayu lebih rendah dibandingkan naungan paranet ditandai dengan tinggi tanaman, rasio luas daun, masa luas daun kedelai berturutturut $10 \%, 7-23 \%$, dan 31-40\% lebih rendah dibandingkan naungan paranet, namun menyebabkan laju pertumbuhan, laju asimilasi bersih, dan hasil kedelai berturut-turut 4\%, $6 \%$, dan $72.88 \%$ lebih tinggi dari naungan paranet. Varietas toleran naungan Dena 1 dan Dena 2 memberikan hasil yang tinggi saat ditanam pada ketiga jenis naungan, sedangkan varietas kurang toleran seperti Panderman dan Grobogan memberikan hasil yang semakin rendah pada cekaman naungan yang lebih tinggi yaitu naungan paranet dan jagung. Tanaman jagung memberikan efek naungan yang hampir sama pada naungan paranet $50 \%$.

\section{UCAPAN TERIMA KASIH}

Ucapan terima kasih penulis sampaikan kepada Dr. Titik Sundari atas bimbingannya dalam pelaksanaan penelitian dan penulisan makalah.

\section{DAFTAR PUSTAKA}

Addo-Quaye, A.A., A.A. Darkwa, G.K. Ocloo. 2011. Growth analysis of component crops in a maizesoybean intercropping system as affected by time of planting and spatial arrangement. ARPN J. Agric. Biol. Sci. 6:34-44.
Balitkabi. 2016. Deskripsi Varietas Unggul Aneka Kacang dan Umbi.

Cheng, X., M. Yu, G.G. Wang, T. Wu, C. Zhang. 2013. Growth, morphology and biomass allocation in response to light gradient in five subtropical evergreen broadleaved tree seedlings. J. Trop. For. Sci. 25:537546.

Chairudin, Efendi, Sabaruddin. 2015. Dampak naungan terhadap perubahan karakter agronomi dan morfofisiologi daun pada tanaman kedelai (Glycine max (L.) Merrill). J. Floratek 10:26-35.

Gardner, F.P., R.B. Pearce, R.L. Mitchell. 1991. Fisiologi Tanaman Budidaya. H. Susilo (penterjemah). Cet 1. UI-Press.

Hamdani, J.S., Sumadi, Y.R. Suriadinata, L. Martins. 2016. Pengaruh naungan dan zat pengatur tumbuh terhadap pertumbuhan dan hasil tanaman kentang kultivar atlantik di dataran medium. J. Agron. Indonesia 44:33-39.

Haque, M.M., M. Hasanuzzaman, M.L. Rahman. 2009. Effect of light intensity on the morpho-physiology and yield of bottle gourd (Lagenaria vulgaris). Acad. J. Plant Sci. 2:158-161.

Jenabiyan, M., H. Pirdashti, Y. Yaghoubian. 2014. The combined effect of cold and light intensity stress on some morphological and physiological parameters in two soybean (Glycine max L) cultivars. Int. J. Biosci. 5:189-197.

Juraimi, A.S., D.S.H. Drennan, N. Anuar. 2004. The effects of shading on the growth, development and partitioning of biomass in bermuda grass (Cynodon dactylon (L.) Pers.). J. Biol. Sci. 4:756-762.

Kisman, N. Khumaida, Trikoesoemaningtyas, Sobir, D. Sopandie. 2007. Karakter morfo-fisiologi daun, penciri adaptasi kedelai terhadap intensitas cahaya rendah. Bul. Agron. 35:96-102.

Koike,Y. 2013. Effects of irradiance level on the growth and photosynthesis of salvia. Int. J. Environ. Sci. Dev. 4:478-482.

Muhuria, L., K. N. Tyas, N. Khumaida, Trikoesoemaningtyas, D. Sopandie. 2006. Adaptasi tanaman kedelai terhadap intensitas cahaya rendah: karakter daun untuk efisiensi penangkapan cahaya. Bul. Agron. 34:133-140. 
Peng, X., N.V. Thevathasan, A.M. Gordon, I. Mohammed, P. Gao.2015. Photosynthetic response of soybean to microclimate in 26-year-old tree-based intercropping systems in Southern Ontario, Canada. PLOS ONE10(6): e0129467. https://doi.org/10.1371/ journal.pone.0129467.

Perrin, P.M., F.J.G. Mitchell1. 2013. Effects of shade on growth, biomass allocation and leaf morphology in European yew (Taxus baccata L.). Eur. J. For. Res. 132:211-218.
Sundari, T., G.W.A. Susanto. 2015. Pertumbuhan dan hasil biji genotipe kedelai di berbagai intensitas naungan. Pen. Pert. Tan. Pangan 34:203-218.

Sundari, T., N. Nugrahaeni, G.W.A. Susanto. 2016. Interaksi genotipe $\mathrm{x}$ lingkungan dan stabilitas hasil biji kedelai toleran naungan. J. Agron. Indonesia 44:16-25. 